\title{
Influence of Media Video Screencast O Matic has an Effect on Learning Motivation in Science Learning
}

\author{
Dwi Warti Utami ${ }^{1}$, Ristiana Dyah Puwandari ${ }^{2}$ \\ $\{\underline{\text { dwiwartiutami@gmail.com }}=\underline{\text { ristianadyah } @ \text { yahoo.com² }}=$ \} \\ ${ }^{1}$ SDN 2 Parakancanggah Banjarnegara \\ ${ }^{2}$ Universitas Muhammadiyah Purwokerto
}

\begin{abstract}
Learning media has an important role as a learning aid. Automatic screencast can affect learning motivation in science learning. This study aims to see the influence of video screencast automatic media to learning motivation. The method used in this research is literature study method. The type of data used is secondary data. The data obtained were collected, analyzed, and concluded to get conclusions about the literature study. Based on the research results, literature studies from several research results and journal articles show that the automatic screencast video media has an effect on learning motivation in science learning.
\end{abstract}

Keywords: screencast automatic, learning motivation, science learning

\section{Introduction}

Education is a critical activity that prepares the next generation to live in the complexities of social, economic, and scientific modernization, as well as science and technology. Every effort, the effect of protection and assistance provided to children is aimed at maturing children or, more specifically, assisting children in carrying out their own life tasks[1].

In a concrete operational sense, the children's condition is able to function their minds to think logically about something concrete or real. Logical thinking takes the place of intuitive thinking (instinct) if it can be applied to concrete or specific examples. [2]. When studying science, abstract materials are not included with things that can help students understand the material. Science learning should be made more meaningful by using learning media, so that students are more motivated and eager to participate in the learning process. In such a case, it is possible to pursue it by providing a learning medium that can arouse interest.

The problems that still occur in science learning given by teachers are still focused on teachers, learning activities are still running conventionally, motivation in learning in schools is still low and the lack of use of media in learning in science learning. This shows that the goal of the 2013 curriculum, which is to form productive, creative, innovative Indonesians, through strengthening integrated attitudes, knowledge and skills has not been implemented properly.

When compared to the same information in its own intellectual format, video is a more powerful tool for communicating messages that inspire, emphasize, enhance, and persuade [3].

Video is more effective in conveying information because only video can cover all of the requirements for obtaining information. Video media is a learning medium that can communicate learning messages more strongly and assertively, inspires, enhances, and persuades students in learning, generates excitement in the learning process, and improves student achievement results [4]. The learning process can be repeated as many times as necessary to ensure that students fully comprehend the learning material. 


\section{Research methods}

This research is a literature review research. The data taken in this study is secondary data. Secondary data is data taken not from direct observers but from the results of research by previous researchers. The data collection method used in this research is the documentation method. The documentation method is a systematic data collection procedure for reviewing both printed and electronic documents [5]. The documentation method is a data collection method by finding or extracting data from literature related to what is meant in the problem formulation. The data analysis used in this research is bibliographic annotation analysis. Annotation means a simple conclusion from an article, book, journal, or some other written source, while a bibliography is defined as a list of sources of a topic[6].

\section{Results and Discussion}

Learning contains the meaning of facilitating or helping initiatives for learners (people who learn) [7]. One form of technology implementation in education is media to facilitate learning. One of the media used in learning and it is believed to be able to stimulate students' interest more in lectures is the media, namely screencast o matic. A screencast is a computer layer output digital recorder, also known as a video screen capture, containing audio narration. Screencast O Matic is a java-based software that can be used for users of the Windows XP, Windows Vista and Windows 7 operating systems [7].

Screencast O Matic provides a free software service that allows users to record all display services and movements of the monitor screen, be it cursor movements and indicator clicks, easy to use, can add descriptions or comments easily. Video is an interesting learning media. Learning videos can be made with several techniques, one of which is screencasting [8].

A screencast or also known as a video screen capture or screen recorder is digitally from a computer display which is often accompanied by a guide narrative recorded using a microphone. Learning videos using the screencast technique have many types of tutorials, for example, tutorials on using software or they can be in the form of exposures. So it is highly recommended in teaching and learning activities [5]. It can be concluded that automatic screencast is software that records all learning media into a learning video and can be shared through various social media models such as YouTube, WhatsApp, blogs and others.

Motivation is really needed by someone from time to time to act and do something because motivation aims to provide encouragement or direction for an activity. A person's motivation cannot be seen as real because the motivation comes from within that person. Motivation is a process that occurs in a person and we cannot see it or touch it, we have to infer from what people say or do [9]. In learning activities, motivation is the driving force within students that causes learning activities and ensures the continuity of learning activities, so that the goals desired by learning subjects can be achieved. Motivation and learning are two things that influence each other [10].

Motivation has an important position in achieving predetermined learning goals. The emergence of motivation is not solely from the students themselves but the teacher must be involved to motivate student learning. The existence of motivation will provide enthusiasm so that students will know the direction of learning. Motivation to learn can arise when students have a desire to learn. Therefore, both intrinsic and extrinsic motivation must exist in students so that the learning objectives that have been formulated can be achieved optimally [11].

Based on the background description and literature review, a suitable alternative to address the lack of motivation to learn in science learning. The use of learning media using automatic video screencasts has an effect on increasing motivation in science learning, that the media plays a very important role in the learning process[10]. 
In learning activities, motivation is the driving force within students that causes learning activities and ensures the continuity of learning activities, so that the goals desired by learning subjects can be achieved. Motivation and learning are two things that influence each other. Screencast O Matic whose use is windows activity and voice recording which can also replace direct experience in learning [13].Through the use of learning media, it affects learning motivation in science learning[14]. Based on the research data collection, it shows that the automatic screencast video media has an effect on the motivation to learn science learning.

\section{Conclusions}

Based on the background of the problem and the research results of the literature study presented, it can be concluded that the use of learning media with video screencast o matic can affect learning motivation in science learning. The author hopes this research is useful as an alternative study for teachers and related parties in building independence and creativity of students in elementary schools.

\section{References}

[1] Rahim A. Hubungan Antara Resiliensi Dengan Motivasi Belajar (Pada Siswa Sekolah Menengah Atas Negeri 1 Long Ikis). Jurnal Fakultas Ilmu Sosial Dan Ilmu Politik. 2017;5(3):427-40.

[2] Emda A. Kedudukan motivasi belajar siswa dalam pembelajaran. Lantanida Journal. 2018 Mar 15;5(2):172-82.

[3] Aminudin A. Media Pembelajaran Bahasa Arab. Al-MUNZIR. 2014 Nov 1;7(2):13-28.

[4] Arsyillah, B. T., \&Muhid, A. (2020). Pendidikan Multikultural Dalam Membentuk Karakter Pemuda di Perguruan Tinggi. Al-Fikr: Jurnal Pendidikan Islam, 6(1), 17-26

[5] Kurniawan D, Dewi SV. Pengembangan perangkat pembelajaran dengan media screencast-o-matic mata kuliah kalkulus 2 menggunakan model 4-D Thiagarajan. Jurnal Siliwangi: Seri Pendidikan. 2017 Jul 25;3(1).

[6] Munjiatun M. Penguatan Pendidikan Karakter: Antara Paradigma dan Pendekatan. Jurnal Kependidikan. 2018 Nov 30;6(2):334-49.

[7] Bowen GA. Document analysis as a qualitative research method. Qualitative research journal. 2009 Aug 3.

[8] Suryanto H. Pengembangan multimedia e-learning berbasis screencast-o-matic pada pembelajaran matematika untuk siswa sekolah menengah pertama kelas VII. Devosi: Jurnal Teknologi Pembelajaran. 2015;5(1):11-21.

[9] Bujuri DA. Analisis perkembangan kognitif anak usia dasar dan implikasinya dalam kegiatan belajar mengajar. LITERASI (Jurnal Ilmu Pendidikan). 2018 Aug 24;9(1):37-50.

[9] Hilmi AF. Utilization of Audio Visual Media to Improve Student Learning Result in IPS Learning. International Journal Pedagogy of Social Studies. 2017;2(1):88-103.

[10] Soimah I. Pengaruh media pembelajaran berbasis komputer terhadap hasil belajar IPA ditinjau dari motivasi belajar siswa. Natural: Jurnal Ilmiah Pendidikan IPA. 2018 Mar $1 ; 5(1): 38-44$.

[11] Ariyati T. Peningkatan Kemampuan Membaca Permulaan Melalui Penggunaan Media Gambar Berbasis Permainan. Dinamika Jurnal Ilmiah Pendidikan Dasar. 2015;7(1).

[12] Handhika J. Efektivitas media pembelajaran IM3 ditinjau dari motivasi belajar. Jurnal Pendidikan IPA Indonesia. 2012;1(2).

[13] Nyoman Jampel, Kadek Riza Puspita. 2017. Peningkatan hasil belajar siswa sekolah dasar melalui aktivitas pembelajran mengamati berbantuan audiovisual. International Journal of Education. Vol 1 No 3. 197-102 
[14] Dewi SV. Efektivitas penggunaan media Screencast O-Matic pada mata kuliah kalkulus integral terhadap hasil belajar mahasiswa. JP3M (Jurnal Penelitian Pendidikan dan Pengajaran Matematika). 2016 Mar 30;2(1):61-6. 